\title{
6 Parameters and Pathways
}

\author{
Agency in the Case of the Southern African Development \\ Community
}

Stacey Links

\begin{abstract}
Chapter 6 provides an in-depth analysis of the Southern African Development Community (SADC) and its interaction with China through the BRI. The chapter explores the agency of African actors, specifically the agency of SADC as a regional power. The chapter's focus on the often-overlooked SADC demonstrates the reach of the BRI as well as the relevance of this project for seemingly 'distant' locales. The chapter takes a deductive approach to agency where agents are placed at the centre of the analysis and themselves demarcate agency. This agent-oriented perspective circumvents the paternalism of imposed definitions, placing definitional power with the actors themselves. The chapter argues this can provide the foundations of an open and empowered conversation on international relations.
\end{abstract}

Keywords: Belt and Road Initiative, China, agency, Africa, Southern African Development Community, SADC

At this stage, the main focus should be on just maybe speaking up about opportunities in terms of what is it that we as SADC can benefit from strong ties [sic] with the Chinese and what is it that the Chinese can benefit if they get into formal ties with SADC in terms of cooperation. - SADC interview respondent (2019)

Much of the research into China and Africa relations to date has focused on the characteristic bilateral relations between individual African states and

Schneider, Florian (ed.), Global Perspectives on China's Belt and Road Initiative: Asserting Agency through Regional Connectivity. Amsterdam, Amsterdam University Press 2021 DOI: $10.5117 / 9789463727853 \_$CHO6 
China. Though this constitutes a large part of China-Africa engagement, this focus has overshadowed the study of the relations between collective bodies and China as well as the multilateral engagements of African actors with China. Exceptions are studies looking at the African Union (AU) and the Forum on China-Africa Cooperation (FOCAC) (Delgado 2015; Eom et al. 2018; Ukeje \& Tariku 2018). This bilateral focus in part reflects the most dominant and visible form of China-Africa engagement. However, it also relates to the scholarly goal of disaggregating China-Africa engagement. While generalizable claims about China-Africa relations from a macro perspective have their merits, particularly from the perspective of broader continental commonalities, scholars have underscored the importance of looking at a wider range of actors in order to more holistically ascertain the range of agendas, relations, and interactions that exist beyond the state level (Brautigam 2009; Mohan \& Lampert 2013). This has led to an expansion of research agendas to include the analysis of the relations that African cities, local communities, civil society, the media, and business have with China and Chinese actors (Rebol 2010; Samy 2010; Mohan and Tan-Mullins 2009). These inquiries often present a lens through which either support or opposition, and most usually opposition, to increasing Chinese presence on the continent is gauged (Lee 2009; HRW 2011). Though far from complete, this expansion of the types of unit being analysed has contributed to demystifying (or myth-busting) public discourses on these relations.

Despite this incremental inclusion of actors across the political, economic, and social landscape, less attention has been paid to engagement at the supra-national level - with the notable exception of studies looking at the African Union. Supra-national structures such as regional bodies have been noticeably absent from discussions on China-Africa relations, despite their important role as coordinating bodies for regional integration and development on the continent. This absence might be attributed to the relative lack of power and success that these actors enjoy vis-à-vis the state in the African context. It might also be attributed to a dearth of knowledge about these bodies outside of specialized scholarship and expertise on regional bodies and/or Africa's political economy (for overviews of regionalism in Africa, see Söderbaum 2009: 487-489; Postel-Vinay 2007).

A further focus of this chapter is agency. As discussed in the previous overview chapter, the specific question of African agency is frequently neglected or wholly absent in policy and scholarly fields of international relations (Fisher 2018; Brown 2012; Shaw 2015). This is in part attributable to the Eurocentric nature of IR scholarship, which has treated African actors as mere objects of inquiry as opposed to agents in their own right (ibid.; 
Seth 2011; Jones 2006). This trend is also visible in prominent perceptions of China-Africa engagement, where the emphasis has been placed on China as the all-powerful actor (singular) that acts upon an agent-less Africa (Quinn 2011; Van Mead 2018; US Senate Committee on Foreign Relations 2011). Equally, the idea of Africa as victim to the 'China threat' is embedded in similar assumptions. Taking seriously critical IR scholarship, this chapter seeks to remedy the partial and Eurocentric nature of IR (and subsequent understanding of China-Africa relations) by reinserting African actors and their agency(ies) in scholarly analyses.

This chapter sets out to first establish the relationship of the Southern African Development Community (SADC) with China and the BRI more specifically, and then, secondly, to assess from the agent's perspective what agency entails. This study does not seek to present an imposed definition of agency that is traced through various processes. Instead, the chapter is focused on exploring agency from the perspective of the agent. This means that while it adopts a base definition of agency as the ability of actors to take decisions in the interest of goals, this definition is engaged loosely in order to leave room for alternative iterations of the concept.

Thus, while states remain indispensable players in China-Africa relations their dominance in analyses has overshadowed the range of actors that are noteworthy of attention. Equally, though African agency is undoubtedly challenged by structural constraints, as has been discussed in the overview chapter, the range of agencies at work has also been neglected, which has simplified analyses. This chapter seeks to tackle these superficial and simplistic characterizations of both actors beyond the state and the role of agenc(ies) in discourses on China-Africa relations. It does this by investigating the engagement of SADC as a principal Regional Economic Community, with China and the BRI.

There is a lack of knowledge about the Southern African Development Community's relations with China and the BRI when compared, for example, with the East African Community (EAC). This lack of knowledge renders it a specifically interesting case from which to investigate the issue of agency. Given the synergies of the BRI's aims and the Southern African Development Community's regional integration goals, it is hoped that this case can provide insight into how agency is conceptualized and exercised at the African regional level. It specifically seeks to ascertain the Southern African Development Community's agency since the release of the BRI white paper in March 2015. The chapter's analysis is based on field research interviews conducted at the Southern African Development Community's headquarters in Gaborone, Botswana, as well as complementary expert interviews with 
individuals from the South African Institute of International Affairs (SAIIA) in Johannesburg, South Africa, which were conducted in October 2019.

\section{China, the BRI, and Africa's Regions}

As has been covered in the preceding overview chapter, Africa was incorporated relatively late into China's BRI. A notable development, however, has been the change in the wider continent's previously relatively marginal role to the BRI since the release of China's 2015 white paper. This white paper broadened the BRI project to encompass regions beyond the initially outlined geographical 'confines' (NDRC 2015). Given the common practice of retroactively including projects, the scope for the BRI in Africa widened (Breuer 2017). The result has been the signing of MoUs across the continent under the auspices of the BRI. South Africa - arguably the furthest away from the 'traditional' map - signed a MoU in 2015. Egypt signed one in 2016. Then both Kenya and Ethiopia signed MoUs in 2017 (Alden et al. 2017).

Relations between China and Africa's regional organizations were previously evident (for example, the relations China has with the African Union, Southern African Development Community, the Economic Community of West African States, and the Common Market for Eastern and Southern Africa). However, the BRI has brought the regional dimension of China-Africa engagement into greater relief and contributed to what Davies has termed 'China's commercial positivism towards African economies' (Davies 2008: 152). Within the context of the BRI, East Africa stands out as a regional focal point, most notably because of its inclusion as an indispensable geographical node of the 'original' One Belt One Road map. Demissie (2018) describes the East African region as the foremost beneficiary of the BRI in Africa, where projects have focused on transregionalism and include ports, naval bases, Special Economic Zones (SEZs), and rail connectivity (ibid.: 74). In this area, for example, it is noted that economic integration has already increased between Ethiopia and Djibouti because of cooperation (ibid.: 75). Despite these successes, the broader experiences of African states with new SEZs on the continent have highlighted that 'African governments have failed to think ahead to how SEZs can improve either their contribution to global trade or create links with global supply-chains' (Okere 2019). These mixed results display the continued challenge of productive regionalism on the continent and raise questions about avenues for African development.

Along with other challenges of China-Africa cooperation, much of the onus to harness the opportunities presented by Chinese investment and the 
BRI has been placed on African states and actors. Implicit in these perspectives is the idea that China's investments do in fact provide opportunities for the continent (Lin and Wang 2014; Kaplinsky 2013; Samy 2010). These observers suggest that while challenges persist regarding Chinese-African cooperation, the opportunities have not been effectively or adequately harnessed by all actors (Chen 2016; Ndzendze \& Zumbika-Van Hoeymissen 2018; Okere 2019). It is this assumption regarding the failure of African actors to harness opportunities that leads to the central question of this chapter. Specifically, this question is: Why have actors such as the Southern African Development Community not harnessed the apparent opportunities provided by China despite China's continued reiteration of the need for African ownership of relations? ${ }^{1}$ Undoubtedly a host of factors contribute to the success of China-Africa engagement and hinge upon how actors themselves define 'success' in relation to their diverse goals. This chapter takes the assumption that all actors hold agency (as has been elaborated on in the overview chapter) and takes the base definition of agency as the capacity to hold specific interests or goals. Based on this, the chapter seeks to understand the Southern African Development Community's agency by exploring its specific interests and goals as well as how the achievement of these is navigated through its engagement, or lack of engagement, with China. The chapter will also pay attention to how both structural and agent-related variables are seen by the agent to play a role in their exercising of agency.

\section{Regional Economic Communities (RECs)}

Within the African context regional economic communities (RECs) present vehicles through which regional integration is pursued. It is hoped that such integration will 'enable the continent to negotiate more effectively with other economic actors in the global economy' for the goals of poverty alleviation and broad-based development (Uzodike 2009: 28). Regional configurations in Africa such as the Economic Community of West African States (ECOWAS), the East African Community (EAC), and the Southern African Development Community (SADC) have featured in African political, social, and economic

1 See, for example, Sun et al. (2017:53), who cite a Chinese diplomat underscoring that 'we have been clear on how we'd like to see our relationships in Africa evolve. What would be tremendously helpful for us is if we could get that same level of clarity from our African counterparts.' Ownership in this context therefore refers to the extent to which African actors drive the terms and conditions of relations. 
research, policy, and debate. However, many outside of Africa, or outside of specialized fields of African political economy and African development, are not necessarily aware of their existence or prominence. These RECs share common goals, all seeking to deepen regional cooperation and development. However, they are trying to achieve these goals in different ways (for example, through either free trade, common markets, or customs unions) and have had varied levels of success as well as equally varied challenges (language, political systems, conflict, level of development) (Uzodike 2009; De Melo 2013; Anyanwu et al. 2014; Bronauer \& Yoon 2018).

Despite the dominance of bilateral relations within China-Africa engagement, BRI initiatives and close relations with China have also been harnessed at a multilateral regional level. This has been carried out most notably by the East African Community (EAC), which has geographical proximity to the 'new Silk Road'. At the time of research, however, markedly absent from discussions about China's engagement at the regional level (and from discussion about the BRI) was any discussion of the Southern African region and the Southern African Development Community in particular. At least, this was the case in public discourse. Despite countries in the region having strong bilateral relations with China (with the exception of Swaziland), anecdotal discussions revealed that not much was or would be happening between the regional body of the Southern African Development Community and China or the BRI. This fit the general assumption that China's engagement on the continent (and the BRI more specifically) is focused on areas with direct interest to China, despite evidence to the contrary (see Brautigam 2009). The lack of visible or notable engagement between the Southern African Development Community and China or the BRI has therefore been assumed to be the result of the region's relative lack of direct interest to the BRI, when compared with the East African region. This is despite the fact that the Southern African Development Community is one of the largest regional economic communities with fifteen member states. In light of the significant cooperation between China and regional economic communities such as the East African Community, this chapter was prompted to explore the reasons why there is a seeming lack of engagement between the Southern African Development Community and China, despite China's strong bilateral ties with states in this region. More specifically it was driven by the impetus to understand the role of agency (defined as the ability of actors to hold interests/goals) in this apparent lack of engagement and in turn to question how the Southern African Development Community's interests and goals are supported or not supported by its relations with China and/or the BRI. 


\section{Contested Agency}

In the context of China-Africa relations, agency has frequently been equated with a normative 'good'. This has meant much of the focus has been on an approach that is a form of activism and equates agency with grassroots movements and local communities (thus sub-state actors). This approach seeks to counter large-scale Chinese projects and Chinese influence on the African continent more broadly (whether this be with regard to nonconsultative projects that impact livelihoods of communities and drive communities out, or with regard to uprisings against unfair labour practices). The result has been that agency has become synonymous with activism that is against Chinese presence in Africa and broader anti-Chinese sentiment (HRW 2011; HRW 2006). Conversely, if and when agency is seen to be successfully harnessed by African actors in popular discourse, it is often directly related to the exercise of absolute or hard power. For this reason, agency is characterized as almost only ever being successfully exercised by corrupt and power-hungry elites. This take has become commonplace in analyses of China-Africa relations (French 2014; Heydarian 2015; Taylor 2008).

At the same time, there have been normative evaluations of agency that have interpreted all cases of African agency as a moral 'win' against the powers that be. Van Staden et al. (2018) note this, writing that

there is a belief that any act of agency by weaker actors within a system dominated by global powers is a normative good, because that necessarily challenges the lopsided power hierarchy. This outlook complicates the analysis of African agency because it ascribes moral purpose to the conduct of African actors because they occupy a weaker position compared to major powers. $(7-8)$

In the same vein, Murray-Evans (2015: 1847) has stated that:

Much of the recent African agency literature conceptualizes agency as the ability of African actors to have a significant impact on international political processes. This literature also often equates African agency with resistance to externally imposed policies and ideas and perhaps even with the ability to bring about progressive or emancipatory structural change.

All these cases demonstrate the couching of agency in normative frameworks, further complicating precise and conceptually clear research on agency. This reductive and often normative or political understanding of 
agency is eschewed in this chapter, which looks at agency in as neutral a light as possible. It does so inductively, by using an agent-oriented approach, which views agency from the position of the agent. In so doing it does not presume a fixed definition or normative stance on how, and to what end, agency is exercised. Instead, by taking an open-ended approach, the agent is placed at the centre of understanding how agency operates, underscoring agency as a context-bound variable that resides largely in the 'eye of the beholder'.

This chapter considers the complexities, as well as the specificities, of African agency(ies). These complexities, which include structural constraints, the centrality of identity, and history, have also been discussed in the overview chapter of this volume about the BRI and the African continent as a whole. For the examination of agency, regional economic communities (RECs) provide an interesting case of how actors with limited power (relative to the state) exercise agency in potentially creative and/or strategic ways. The question as to how the Southern African Development Community holds agency and what its constraints are is asked in an open-ended manner to allow for as wide as possible an understanding of agency. An agent-focused approach complements this inductive framework. In this way, it is hoped that the chapter can shed new light on how agency is perceived and exercised.

\section{The Southern African Development Community's Interests, Goals, and Challenges}

This chapter defines agency as the ability of an actor to hold interests and goals. It is therefore necessary to briefly discuss these interests and goals as they relate to the Southern African Development Community. Moreover, by adopting an agent-oriented perspective these interests and goals are limited to how the Southern African Development Community as an organization presents these itself. Equally it is necessary to caveat the discussion of the Southern African Development Community by pointing out some of the foremost challenges faced by the body that impact its autonomy.

Founded in 1992, the Southern African Development Community represents one of the largest regional economic communities (RECs) on the African continent (after the Common Market for Eastern and Southern Africa, the Economic Community of West African States, and the Community of Sahel-Saharan States). The Southern African Development Community is comprised of sixteen member states. Its primary objectives are stated to be achieving development and economic growth, poverty alleviation, improvement of life standards, as well as supporting socially disadvantaged groups all 
through a process of regional integration (SADC 2012). The Southern African Development Community secretariat is thus the region's coordinating body with a mission to 'provide strategic expertise and co-ordinate the harmonization of policies and strategies to accelerate Regional Integration and sustainable development' (ibid.: Vision, Mission \& Mandate).

A key agenda is the Southern African Development Community's Regional Indicative Strategic Development Plan (RISDP), which represents the operational framework for achieving specific goals set out in the Common Agenda. Importantly, the RISDP has a fifteen-year span (2005-2020), concluding in 2020. It sets out milestones and targets across a number of listed priority areas such as poverty eradication, infrastructure support, and environmental/ sustainable development (amongst others). Aside from the specifics laid out in the RISDP, the Southern African Development Community's focus on regional integration is best captured in its five directorates or themes, which are 1) Industrial Development and Trade; 2) Finance, Investment, and Customs; 3) Infrastructure \& Services; 4) Food Agriculture \& Natural Resources; and 5) Social \& Human Development; all are supported by the Southern African Development Community's specific policies and strategies (see ibid.: Overview, Common Agenda). Beyond regional integration, one of the goals of the Southern African Development Community is to develop the region to the degree that it can be competitive in international relations and the world economy. Regional integration, the establishment of a vision of a shared future, and the creation of a regional community are cited as necessary components to achieve this broader goal (SADC 2012: Vision, Mission \& Mandate).

Specifically, the Southern African Development Community has identified infrastructure as one of the major contributing factors for economic growth and poverty reduction in the region. The present state of infrastructure as well as the infrastructure gap between the Southern African Development Community region and the more developed countries constitutes a serious handicap to the region's production and competitiveness' (ibid.: Project Preparation Financing). This is captured in the Regional Infrastructure Development Master Plan (RIDMP) of 2012. This plan underscores the importance placed on infrastructure development as a fundamental cornerstone of regional integration (ibid.: RIDMP Executive Summary).

\section{Interviews}

In the following section, the chapter provides a thematic discussion of the key concepts that emerged in the range of open-ended interviews conducted 
with officials from the Southern African Development Community as well as experts at the South African Institute of International Affairs in October 2019. The interviews were open-ended to give interviewees the broadest possible scope to address issues related to relations between China and the Southern African Development Community, to discuss challenges faced by the Southern African Development Community, as well to speak about the question of agency. The four main themes focus on the Southern African Development Community's interests, the nature, and modes of engagement between the Southern African Development Community and its partners, and structural considerations.

\section{Interests}

As a point of departure, the Southern African Development Community officials that were interviewed felt it necessary to extensively outline the organization's structure and priority areas. They underscored that industrialization, infrastructure, peace and security, social and human development were the main focal points. They mentioned that the organization was in the process of developing strategies for after the Regional Indicative Strategic Development Plan ends in 2020 that would maintain the same priorities for the region. The interviewees stated that infrastructure was unique in its nature, being particularly capital intensive and thus requiring significant financing. However, they suggested that this capital-intensive nature of the sector was not particular to the Southern African Development Community region, but was an industry-wide reality. One of the respondents noted that 'we give a lot of importance to infrastructure development' and the idea of 'infrastructure in support of regional integration' (SADC interview 2019). They further indicated the centrality of this area to the Southern African Development Community's interests. The overlapping interest in infrastructure of Chinese investments in Africa and the Southern African Development Community was mentioned, underscoring the importance attributed to common interests. Despite this overlap, the respondents mentioned that for any project to qualify for financing, it 'must link with the priorities of the region [...] in a way that benefits the region' (ibid.). The fact that this was reiterated on several occasions shows the importance that SADC places on seeing that its interests are fulfilled.

The importance of quality support was also emphasized by several of the interviewees. This perhaps relates to the commonly held belief about the poor-quality projects deriving from China (Farrell 2016). The kind of quality control that is carried out on new projects includes resource mobilization 
checklists and involves a technical review of support and legal units, as well as a review of the resource mobilization allocation framework. The interviewees noted that at the Southern African Development Community: 'we have a very structured engagement mechanism' (ibid.). They reiterated that not just any project would be taken on but that strict guidelines had to be followed. They stated that the Southern African Development Community would not sign off on engagements that did not meet their very stringent needs. These decision-making capacities and forms of accountability arguably allow for agency to be asserted vis-à-vis powers like China and provide the organization with a framework within which to pursue their interests. The weight given to this issue by the respondents emphasized that China is unable to 'buy' or 'intercept' the priorities of the Southern African Development Community. This was captured in a statement made by one of the interviewees, who said: 'If it's not aligned to [the Southern African Development Community's] priorities, the cooperation would be aborted' (ibid.). These regulatory frameworks guide the Southern African Development Community's projects and should in theory allow for the pursuit of specific goals and interests. However, the reality of how this pans out in the context of cooperation between the Southern African Development Community and China remains to be seen. Nevertheless, these statements give insight into how the agent (in this case the Southern African Development Community) emphasizes the importance of both interest and mutual interest. As will be discussed later, despite this initial optimistic and arguably simplistic understanding, the interviewees also noted the way that effective collaboration depends on the interests of funders themselves.

In demonstrating their drive for cooperation, respondents tended to express their position in terms similar to the following: 'What is it that we as [the Southern African Development Community] can benefit from [through] strong ties with the Chinese? And what is it that the Chinese can benefit [from] if they get into formal ties with [the Southern African Development Community] in terms of cooperation?' (ibid.). These kinds of statements display an approach that focuses on what each party can get out of cooperation. This 'win-win' focus - though never explicitly mentioned as such - was evident throughout the discussions. Statements relating to this revolved around the importance of ensuring that both parties see their interests met. This indicates that the Southern African Development Community sees their relations with China as being mutual cooperation, as opposed to being zero-sum. The interviewees therefore challenged the idea that African actors are worse off in their cooperation with China. Instead, these interviewees reiterated the importance of seeing the benefits 
of cooperation for African actors: 'At this stage, really, it would be more useful to focus more on the opportunities' (ibid.).

In relation to the issue of interests, the interviewees also remarked that it was no longer feasible to simply bring funds into Africa. They said that foreign direct investment (FDI) now also needed to contribute to socioeconomic development. It might do this, for example, by linking African small- and medium-sized enterprises into investors' value chains. While it remains too early to tell whether or not China-Africa cooperation will contribute to socio-economic development in this way, the fact that the interviewees raised this point relates to the idea of agenda setting through the articulation of interests. This agenda-setting role was mentioned by the interviewees as central to agency. One of the experts interviewed remarked that the African continent and the Southern African region are at a critical juncture, where structural factors such as 'rapidly expanding markets, maturing middle classes [and the new] continental free trade agreement' (expert interview 2019b) are being leveraged. This allows for greater agency. The fact that Africa is going through a critical period, combined with the fact that the markets of Europe, North America, and increasingly Asia are highly saturated, has placed the region in a better negotiating position, creating increased room for African actors to exercise agency. In this way, it might be argued that global structural shifts are demonstrating the impact of structural change on agency.

\section{Modes of Engagement}

The Southern African Development Community respondents placed a strong emphasis on the priorities, resource mobilization strategies, and processes of the organization. However, they also mentioned that 'China is more open in terms of modalities, unlike the other partners [where] you have a lot of rules to follow, and processes' (ibid.). They therefore suggested that they saw relations with China as offering a degree of flexibility, or at least a range of options that would seemingly give the Southern African Development Community room to manoeuvre. What precisely these modalities would entail and look like in the context of engagement with China (given the Southern African Development Community's own regulatory frameworks) was, however, not clear, in part due to the fact that relations are still in a relatively early stage.

The interviewees mentioned that coordination between the Southern African Development Community and China 'is still young in terms of achievements [...] [but we have] strong ties with the Chinese partners, with 
Chinese stakeholders, and the Chinese government' (ibid.). The relative newness of these relations means that, while more combative assertions of agency grounded in competing or incompatible interests could characterize future engagement, this early stage of engagement has thus far only dealt with seemingly superficial compatible interests. When probed for possible points of incompatibility, the interviewees made clear that it was not productive to focus on the challenges as they had not experienced any to date. Instead, they were far more optimistic and focused on the opportunities that China and the BRI could bring to the project of regional integration.

Despite the recent nature of engagement, and in contrast to the assumption that the Southern African Development Community and China have no firm relations to speak of, the interviewees noted that a memorandum of understanding $(\mathrm{MoU})$ between the two parties had been in the making since 2016. More importantly, the establishment of relations and this MoU has been a process largely driven by the Southern African Development Community and not by China. The interviewees suggested that the apparent lack of commitment, and the fact that a MoU had not yet been signed, was a consequence of logistics rather than the existence of conflicting views, troubled negotiations, or a lack of interest on the part of the Southern African Development Community. This contrasts with the perception that the Southern African Development Community has been lacklustre in harnessing the potential opportunities that Chinese investment and cooperation provides. One interviewee, underscoring the drive to cooperate on the part of the Southern African Development Community, remarked that 'once the MoU is signed officially, then we will start aggressive engagement with China' (ibid.). While a MoU is meaningful to signal cooperative intent, how engagement concretely plays out will also be significant.

One of the experts interviewed noted differences in how the BRI was conceptualized, as either predominantly commercial or strictly political, suggesting that these differences necessarily reflected the interwoven nature of business and politics in China (expert interview 2019a.). This way that the BRI combines business and politics was seen by some interviewees as having a bearing on agency. In this view, China-Africa relations (under the BRI and beyond) have come to represent a unique form of engagement, different to Africa's engagement with traditional platforms or partners such as the European Union. Though international relations will always consist of a mixture of politics and business, China is seen as qualitatively distinct from traditional partners, particularly because of its avoidance of political reform in the form of political conditionality. This different 
political approach by China arguably affords a greater degree of agency for actors such as the Southern African Development Community in Africa. However, whether or not the Southern African Development Community is able to leverage this greater potential for agency, considering the structural impediments (as will be covered in the following section), is another question altogether. It is a question that the interviewees largely felt was too early to answer, given the relative silence on the issue of the Southern African Development Community and China at the time of the interviews. Thus far it would seem the biggest assertion of agency has been the initiating of relations by the Southern African Development Community in order to pursue their own agenda and goals. This is contrary to the widely held assumption that China-Africa relations are initiated and driven by Chinese actors and interests (Mohan and Lampert 2013).

Interestingly, after field research interviews were conducted, there was a new development in the relationship. The Chinese government pledged the continuation of development cooperation with the Southern African Development Community after finalizing the Southern African Development Community and China Framework Agreement, which was signed in October 2019 (SADC 2019). Beyond the Framework Agreement, which serves as a MoU, the Chinese delegation notably 'extended an annual grant amounting to US $\$ 100,000$ to the Southern African Development Community Secretariat to support its operational needs and implement activities that are in line with [Southern African Development Community] priorities' (ibid.). While this contribution is towards the operational needs, it will be interesting to see what, if any, Southern African Development Community projects are financed by China in the future. It will be also interesting to watch how these arrangements differ, if at all, from those with traditional partners. How these are negotiated will reveal more about the Southern African Development Community's agency vis-à-vis China and the BRI.

Although limited, these initial engagements have an important bearing on the question of the Southern African Development Community's agency. They speak to a degree of 'action' on the regional body's part. Despite the recent nature of relations, the initiation and pursuit of cooperation from the Southern African Development Community reflects the way in which the body has taken initiative in asserting its interests and agenda vis-à-vis China. Moreover, the Southern African Development Community's apparent unified position in approaching China (which would require consent from its diverse and wide-ranging member states) speaks to a degree of active agency on the part of the regional body. 


\section{Structural Considerations}

The interviews also sought to explore the range of challenges faced by the Southern African Development Community as an organization. It was hoped to reveal ideas around constraints to agency. What emerged was a range of challenges mostly related to structural constraints - the limitations inherent to regional bodies, regionalism, and the process of coordinating regional integration. These limitations include such things as the need for a consensus between member states, as well as the often-cumbersome pipelines with regards to project preparation - from identification to bankable stages (ibid.). The interviewees mentioned the challenges presented by the scope of cooperation: 'There will always be too much ground that needs to be covered' (SADC interview 2019). These challenges are evidently more related to the intrinsic challenges of coordinating regional projects for integration and development. Projects that would fall under the category of cooperation with 'China' or the BRI appear to be no different in this regard. However, the interviewees did mention that China was 'more open' to different modalities. What precisely these different modalities were and how they would either complicate or ease processes was not clear, partially because of the young nature of these relations.

The biggest challenge that the officials noted was the sustainability of programmes in relation to financing:

[The Southern African Development Community] is a member-statedriven organization. We receive contributions from our member states to run the organization. But those contributions are mostly for the [the Southern African Development Community] secretariat coordination, not to implement our programmes. [...] [M] ost of our programmes are still supported through donor support, which is not sustainable. (Ibid.)

From the discussions it was made clear that although the Southern African Development Community has its own set of priorities (not set by external partners), the sources of financing (i.e. financiers) in part dictate what money is spent. In terms of funding the main partner of support remained the EU, which is followed by German cooperation, and then there is the rest, which includes China (ibid.). The interviewees also mentioned that adequate interest from both sides was needed to set up a given project, again reiterating the centrality of compatible interests. The idea that China and the Southern African Development Community's goals were complimentary was presented by the interviewees as an opportunity where both parties' 
interests could be met. A more in-depth comparison of EU and Chinese funding would be needed to assess if there is a difference in amount of room these two sources of funding provide for African agency. At first glance, however, it would seem that cooperation between China and the Southern African Development Community may provide more room for manoeuvrability than cooperation between the EU and the organization, or a different kind of agency. The cooperation between the EU and the Southern African Development Community is often constrained by the dictates of donor approaches (Buzdugan 2013; Hurt 2012).

The experts interviewed noted numerous structural challenges relating to the Southern African Development Community's agency. These can be divided into three broad areas, namely historical legacies that the continent (and an organization like the Southern African Development Community) face, resource constraints, as well as the very nature of regional integration as a project itself (which was also mentioned by the interviewees from the Southern African Development Community). The issues presented by historical legacies were noted by the interviewees as being a continent-wide challenge. This is particularly with regards to the legacies of colonialism that have continued to have tangible effects on the pursuit of regional integration and continental development. It was mentioned that, particularly in infrastructure, different systems inherited from different colonial powers persist in countries across Africa. This presents structural and logistical challenges such as differing railway gauges, different legal systems, and different regulators (expert interview 2019b). As one interviewee noted, 'the whole concept of regional infrastructure is a massive challenge [in Africa]' (ibid.). Agency on the part of a body such as the Southern African Development Community is thus inherently limited by the configuration of the African political and historical landscape. Historical factors were also highlighted as a key difference in the levels of success of the East African Community and the Southern African Development Community. The East African Community's emergence was largely economically driven, in contrast with the Southern African Development Community, which emerged from very specific political rationales that initially sought to relieve the region of its dependence on apartheid South Africa. Corroborating this, another interviewee noted that the Southern African Development Community still has to 'deal with the legacy of its creation' (expert interview 2019d). This legacy presents a further structural impediment to the effective exercise of agency.

This ties into other distinct structural constraints of the region, when compared to the East African Community for example. The Southern African 
Development Community constitutes a much larger geographic region with a wider mix of disparate economies and countries. The countries in the region range from states that are small and landlocked (such as Lesotho, Malawi, Swaziland), to states that are large but arguably unconsolidated (such as the Democratic Republic of Congo), to states that are large but with low population density (such as Namibia and Botswana), and finally to a series of small island states (expert interview 2019c, 2019d). The dominance of the regional hegemon South Africa also presents a structural challenge, especially given the challenges that South Africa itself faces. Thus, while South Africa may enjoy a relatively diversified economy, the socio-economic challenges of unemployment and poverty remain a more immediate priority for the country. A challenge to the Southern African Development Community's exercising of agency lies in the serious developmental and political challenges that each member state faces. Bilateral engagement with China and/or the BRI therefore remains valuable, whereas the broader continental [or regional] dividend' remains a structural challenge (expert interview 2019c). Given the relative underdevelopment of regionalism in SADC, it is no surprise that pressing national concerns are often prioritized over regional agendas.

Another interviewee noted that the Southern African Development Community's constrained resources were also a potential structural barrier to agency (expert interview 2019c). This relates largely to the lack of personnel. The result is a largely understaffed secretariat with an exorbitantly high workload (ibid.). This has made coordinating integration incentives between the middle- and low-income countries that make up the continent and the region even more cumbersome. Perhaps surprisingly, the interviewees did not see the Southern African Development Community's need to finance itself as a constraint. Instead, they pointed to the lack of human resources and appropriate expertise need to provide project preparation (expert interview 2019b). This undoubtedly hampers the organization's ability to pursue and achieve its goals.

Equally relevant, the interviewees also mentioned that regional blocs such as the Southern African Development Community were challenged by their limited mandate and the accompanying limitations on decisionmaking power (ibid.). The very nature of the Southern African Development Community secretariat, which is a purely coordinating body, therefore presents a structural challenge to its agency. Nevertheless, if maintaining cordial relations and respecting member states' wishes is in the organization's interests, then arguably the limited role of the secretariat does not necessarily impact the Southern African Development Community's agency 
to the degree assumed. This highlights the way that the competing interests of an actor may be an obstacle to effective agency.

One thing that was not mentioned by the officials, but which was reiterated by the experts interviewed, was that the agency of a body like the Southern African Development Community when engaging in the BRI should be considered in combination with the structure of the BRI or the lack of such structure. The BRI is a very 'loose idea' with 'loose framing' (i.e. not having a secretariat or headquarters) (expert interview 2019a, 2019d). This looseness means that the structure of the BRI does not act as either a major constraining or an enabling factor for the Southern African Development Community's agency. This will also be affected by any changes to the BRI and its functioning.

The specificities of the African context were also noted as relevant to the Southern African Development Community's agency. Interviewees noted that agency in Africa is often shaped by a lack of structural power and thus exclusion that can result in a 'Global South version of agency' (expert interview 2019a). An important takeaway was that:

[t] here will always be something with structural constraints. So one would need to define agency in relation to how it's exercised in the context of constraints. [...] one model that immediately comes to mind is a tactics and strategy kind of model. To a certain extent, this kind of global south agency always has a strong practical element. (Ibid.)

This form of agency also involves the idea of 'strategic non-compliance' or the ability to 'block' actions that are being taken. Here, agency has as much to do with 'action' as 'inaction'. The above quotation points to the wide array of ways in which agency may be exercised, particularly in the face of structural barriers (expert interview 2019c). The interviewees made a similar point about the assumption that a lack of coordination, unified governments, or lack of articulating what cooperation would look like necessarily means a lack of agency' (expert interview 2019a). Instead, they suggested that these things might not mean a lack of agency. They indicated that the strategic choice of when to use institutional architecture to further particular interests 'itself could be seen as an exercise of agency or decision making' (ibid.). From interviews with officials from the Southern African Development Community it appeared that official frameworks would be used to ensure engagement suited the organization's interests. However, as has already been mentioned, the type of arrangements made remain to be seen. These could very well be different from what traditional partners have pursued. 
Despite these constraints, all respondents reiterated that China and the BRI present a great opportunity for the region's development. The preeminent challenge to agency would be the very nature of the Southern African Development Community's secretariat with its limited mandate and authority:

[I]f we can agree on a very specific way that we want to trade with each other, and we as a region want to trade with the rest of the world, then I think we can start talking about real agency developing; agency in the sense of influencing the development dividends, the way we articulate our particular positions, the way we articulate our expectations, and the way we can insist that our expectations are met. The question for me is whether the SADC secretariat can play that role. (Expert interview 2019c)

In part, then, the call is for a 'much stronger regional integration body' that is able to move beyond the structural limitations of a coordinating body and this secretariat's lack of independence - something which was also highlighted as an obstacle (expert interview 2019d). However, a question is whether this is possible, given the structural challenges that exist in the individual member states and have been described above. This remains a fundamental question and one that is not specific to relations between China and the Southern African Development Community. The main issue is not the dominance of bilateral engagement between China and states in the region, but rather diverging priorities between member states themselves. If the BRI and Chinese cooperation with the Southern African Development Community, given its focus on infrastructure development and structural transformation, is able to successfully incentivize national governments to prioritize and coordinate regional projects, then the Southern African Development Community, as a regional body, could be inadvertently strengthened. This however remains highly speculative.

\section{Discussion}

The interviews conducted for this research provided numerous key insights with regards to the main tenets of agency as conceptualized by officials from the Southern African Development Community secretariat as well as experts in the field. Common concepts related to agency were leverage, influence, interests (and their articulation), as well as agenda-setting and decision-making power. The Southern African Development Community 
itself emphasizes its interests as central to any engagement, supporting the idea that agency at its very fundamental level is the ability of an actor to possesses goals and interests. In relation to its engagement with China, the interviews reflected an active pursuit of interests, related to the task of exercising agency.

What is clear from the interviews is that beyond the formulation, articulation, and pursuit of interests, there exists a strong relational component to understanding the Southern African Development Community's agency. Most notably, the different nature and modes of engagement between Africa and China, when compared to Africa and traditional powers, results in different types or expressions of agency, as either conflicting, complementary, or a mix of both. At this stage, China is presented by those participating in the cooperation as holding (mostly) complementary goals and interests, which has resulted in a more inconspicuous form of agency. This relational dimension of interests and their compatibility emerged from the interviews as a key consideration in understanding agency. The tendency within research to overlook how agency might still be being exercised when the interests of actors are synergistic, or overlap, has narrowed the understanding of agency. A preliminary hypothesis for future research would be that overlapping interests, such as the interests which lie behind Chinese BRI investments and the Southern African Development Community's goals, present greater scope for agency, particularly on the part of the more structurally constrained actor, which in this case is the Southern African Development Community. This arguably affects the effectiveness of agency positively. The inverse would be that more disparate and conflicting interests, such as the interests of the EU and the Southern African Development Community's goals, when in combination with structural constraints, act to limit the effectiveness of agency, particularly on the part of the structurally constrained actor.

Furthermore, the interviewees discussed at length numerous structural factors that impede scope for exercising effective agency. There are various kinds of structural constraints. However, what emerged as an interesting point is the way in which China's engagement (through the BRI) could potentially alleviate some of these constraints. While it remains too early to tell, future engagement will demonstrate how effectively the Southern African Development Community's agency has worked to secure its goals and interests. Here the BRI may contribute to achieving these goals through its focus on key priority areas such as infrastructure. Equally, because of the loose nature of the BRI itself, this platform may provide increased room for the Southern African Development Community to effectively achieve its goals. 
Important aspects, mentioned in both the interviews with the Southern African Development Community officials and the experts, were financing and agenda setting. While the EU remains the largest funder of the Southern African Development Community, how this funding differs from that provided by other funders, as well as the specifics of relations between the EU and the Southern African Development Community, are key considerations in understanding the Southern African Development Community's ability to exert effective agency. An equally important consideration is the nature of relations and the conditions of engagement/ funding between the Southern African Development Community and its funders. Part of this relates to the very nature of the Southern African Development Community's regionalism project. This project is one that is grounded in economic liberalization (Hurt 2012). In the interviews with officials, however, there was little reflection on the origins of the Southern African Development Community's interests as well as the influence of partners on its model of regionalism. An interesting question now is whether, and if so how, engagement with China and the BRI will steer the organization or certain projects in a different direction. A related question is whether the Southern African Development Community's goals and interests will be compromised in considering alternative pathways. Evidently, a degree of mutual interest is required in order for cooperation between the Southern African Development Community and its partners to be successful. However, to what degree this need for mutual interest differs amongst partners and how that affects the effective exercising of agency on the part of the Southern African Development Community remains to be seen.

A notable contribution that this research has made is to confirm the existence of formal relations and the intention for greater cooperation between the Southern African Development Community and China (as well as the BRI). During the research for this chapter, the experts interviewed were not aware of the impending MoU. However, the interviews with officials from the Southern African Development Community came at an opportune time, just as the MoU was being finalized. The fact that there is increasing cooperation between the Southern African Development Community and China contradicts the preliminary assumption that the Southern African Development Community has been apathetic towards such cooperation. It has been found that during this stage the Southern African Development Community has largely driven and instigated cooperation with China demonstrating an active pursuit of interests and thus agency. However, it remains to be seen to what extent the MoU is actionable, and, 
more importantly, whether a truly regional dividend can emerge from this kind of cooperation. This, in part, will reflect the effectiveness of the Southern African Development Community's agency. However, it needs to be assessed in the context of the many structural challenges the organization faces. This point was emphasized by one interviewee, who stressed the need for the Southern African Development Community to have a 'very clear [and] tangible agenda or even a very concrete implementation plan' with 'very clear benchmarks', considering the infrastructure deficit in the region (expert interview 2019c).

Beyond descriptions of how the Southern African Development Community works and what the main challenges to its interests are, the interviews were also insightful regarding how to best research agency. A noticeable challenge, however, was found with asking officials about agency directly. When asked there seemed to be a conflation of the idea of agency as 'the capacity for an actor to act in its interest' with agency as 'an organizational body or branch'. This reflects an evident gap between 'scholarship' on agency and how agency is understood in 'practice' by the agent themselves.

The biggest divergence in the interviews was on the issue of financing as an impediment to agency. The experts interviewed did not mention financing as a significant challenge, whereas the officials from the Southern African Development Community did. That being said, the latter qualified the challenge presented by financing, saying that this was the challenge of satisfying the interests of financiers. Meanwhile, the experts interviewed (in particular, expert interview 2019b) focused on the issue of project preparation and the limited resources in this phase. The interviews with officials from the Southern African Development Community relayed the various financing mechanisms and their respective challenges. Certain pathways for financing were highlighted as more restrictive with regards to agency, while others were seen to provide more leeway. Evidently, this has been recognized as a challenge by the secretariat and is a mechanism through which room for manoeuvre can be created.

One topic worth further exploration that emerged was the relationship between agency and effectiveness, or the question of how one might measure the effectiveness of agency. Important considerations and questions are 1) formulating points to achieve/interests, 2) a seat at the table, 3) to what extent can one shape the agenda, and 4) to what extent can one take this beyond just an agenda item (expert interview 2019d). The issue therefore is not whether agency exists, but rather to what degree it is functional and effective, given structural limitations. 
Despite structural challenges related to the 'form' of the regional body itself, the current setup did not appear to hamper the ability of the Southern African Development Community secretariat to articulate its interests and set agendas. It would seem that 'frequently there is an underestimation of who the African actors are, and particularly the fact that all these African actors are exercising agency in different ways and on different levels' (expert interview 2019a). This also seems to be consensus among experts with regards to the Southern African Development Community and its engagement with China and the BRI. If harnessed strategically, the BRI presents a vehicle through which structural challenges to the region's development can be addressed, thereby complementing the Southern African Development Community's interests.

\section{Conclusion}

This chapter has highlighted the importance of an agent-oriented approach to understanding agency in the African context. Considering the dearth of research into actors beyond the nation state and their relations with China, it has specifically focused on the supra-state level by looking at a regional body, the Southern African Development Community. By shifting the unit of analysis beyond the state, it has uncovered the range of considerations, opportunities, and obstacles that such regional bodies face in the realm of agency. Moreover, by using an inductive approach to agency, certain facets have emerged as central. These are the importance of interests and their articulation through agenda setting. A regional body such as SADC that pursues its interests by actively seeking collaboration with potential financiers such as China, demonstrates a degree of effective agency. Added to this, it emerged that, from the perspective of the agent, agency is shaped (constrained and enabled) by structural and relational factors that are context dependent.

Moreover, the particularities of agency within cooperative spaces and coinciding interests emerged as an often-overlooked area of agency. This is notable in the context of relations between China and Africa, and in the case of relations between the Southern African Development Community and China and the BRI that have been examined in this chapter. Relations between Africa and China provide alternative foci and thus alternative pathways to fostering collaboration when compared with relations between Africa and traditional donors. Highlighting the space for cooperation and complementarity, the Southern African Development Community's agency 
in terms of its relations with China and the BRI is at this early stage limited to cooperative engagement.

This chapter has also highlighted the importance of conflicting and complementary interests as central to understanding agency. These aspects underscore the need to obviate normative judgements on what agency ought to look like if one is to truly 'ascertain' or locate agency. It concludes that alongside the question of whether agency is exercised there is also an altogether separate question that must be asked. This is whether agency is effective, that is, whether agency achieves intended goals or secures interests (such as in the priority area of infrastructure development). This chapter has illuminated why agency has not been explicit or apparent (i.e. complementary interests). However, it has also noted that the effectiveness of this agency remains to be seen.

This chapter has also identified the centrality of structure to the discussion of agency in Africa and in the Southern African Development Community specifically. In this way, the chapter has provided a basis from which to further analyse the potential for China's engagement with the Southern African Development Community, within and outside of the BRI, to contribute to structural transformation in the region. More specifically, the ability of these new partnerships to contribute to the achievement of the Southern African Development Community's goals and interests, which are regional integration through development, specifically in the area of infrastructure, are areas worth exploring more. This will further advance our discussion of how effective the Southern African Development Community's agency is. Equally interesting is the question of whether the efficacy of agency in the case of the Southern African Development Community is dependent on shared interests.

This chapter has served as an introductory and exploratory investigation into the possible dynamics of agency within the Southern African Development Community and between the Southern African Development Community and China and the BRI. Shedding light on the parameters and pathways of agency is becoming increasingly relevant for how actors in Africa, in China, and in third-party states engage one another. Misconstruing agency not only obfuscates the complexities of how regional actors engage the powerhouse that is China and its BRI, but it also runs the risk of oversimplification. This chapter has hopefully managed to underscore the value of an agent-oriented, contextual, and relational approach to agency. 


\section{References}

Alden, Chris, Sidiropoulos, Elizabeth \& Wu, Yu-Shan (2017, May 29). 'China's Belt and Road Initiative: Where Does Africa Fit?' South African Institute of International Affairs (SAIIA). Retrieved 26 March 2020 from http://www.saiia. org.za/opinion-analysis/china-s-belt-and-road-initiative-where-does-africa-fit.

Anyanwu, John C., Conceição, Pedro \& Kayizzi-Mugerwa, Steve (2014). 'Regional Integration in Africa: An Introduction' African Development Review, 26(s1), 1-6. Brautigam, Deborah (2009). The Dragon's Gift: The Real Story of China in Africa. Oxford: Oxford University Press.

Breuer, Julia (2017, July). 'Two Belts, One Road? The Role of Africa in China's Belt \& Road Initiative'. Blichwechsel. Retrieved 26 March 2020 from https://www. asienhaus.de/uploads/tx_news/Blickwechsel_OBOR-Afrika_o1.pdf.

Bronauer, Jan \& Yoon, Ji (2018, August). 'Regional Economic Development in SADC: Taking Stock and Looking Ahead'. Report 25. South African Institute of International Affairs (SAIIA). Retrieved 26 October 2020 from https://saiia.org.za/research/ regional-economic-development-in-sadc-taking-stock-and-looking-ahead/.

Brown, William (2012). 'A Question of Agency: Africa in International Politics'. Third World Quarterly, 33(10), 1889-1908.

Buzdugan, Stephen Robert (2013). 'Regionalism from Without: External Involvement of the EU in Regionalism in Southern Africa'. Review of International Political Economy, 20(4), 917-946.

Chaponnière, Jean-Raphaël (2009). In Meine Pieter van Dijk (ed.), The New Presence of China in Africa (pp.55-82). Amsterdam: Amsterdam University Press.

Chen, Huiping (2016). 'China's One Belt, One Road Initiative and Its Implications for Sino-African Investment Relations'. Transnational Corporations Review, 8(3), 178-182.

Davies, Martyn J. (2008). 'Special Economic Zones: China's Developmental Model Comes to Africa'. In Robert I. Rotberg (ed.), China into Africa: Trade, Aid, and influence (pp. 137-154). Washington, DC: Brookings Institution Press.

Delgado, Daniel Lemus (2015). 'Discourse, Identity and International Development Cooperation: China, Africa and FOCAC'. Asia-Pacific Social Sciences Review, 15(2), 1-18.

De Melo, Jaime (2013, December 3). 'Regional Trade Agreements in Africa: Success or Failure'. International Growth Centre (IGC) blog.

Demissie, Alexander (2018). 'Special Economic Zones: Integrating African Countries in China's Belt and Road Initiative'. In Maximilian Mayer (ed.), Rethinking the Silk Road: China's Belt and Road Initiative and Emerging Eurasian Relations (pp. 69-84). Singapore: Palgrave Macmillan. 
Eom, Janet, et al. (2018). 'The Path Ahead: The 7 th Forum on China-Africa Cooperation'. Briefing Paper no. 1. China Africa Research Initiative.

European Parliament (2008, March 28). 'Report on China's Policy and Its Effects on Africa'. Retrieved 9 July 2020 from https://www.europarl.europa.eu/sides/ getDoc.do?reference=A6-2008-008o\&type=REPORT\&language=EN\&redirect. Farrell, Jamie (2016, August 14). 'China's Undeserved Reputation for Building Bad Infrastructure in Africa'. China Africa Project. Retrieved 21 August 2020 from https://chinaafricaproject.com/podcasts/podcast-infrastructure-china-africajamie-fuller/.

Fidler, Mailyn (2018, March 7). 'African Union Bugged by China: Cyber Espionage as Evidence of Strategic Shifts'. Council on Foreign Relations. March 7. Retrieved 26 May 2020 from http://cfr.org.

Fisher, Jonathan (2020). 'African Agency in International Politics'. In Nic Cheeseman (ed), Oxford Research Encyclopedia of African Politics. Oxford: Oxford University Press

French, Howard (2014). China's Second Continent: How a Million Migrants are Building a New Empire in Africa. New York: Alfred A. Knopf.

Heydarian, Richard Javad (2015, January 20). 'China's Scramble for Africa'. AlJazeera. Retrieved 16 July 2020 from https://www.aljazeera.com/indepth/opinion/2015/01/ china-troops-africa-economic-201511810569508263.html.

HRW (2006, November 2). 'China-Africa Summit: Focus on Human Rights, Not Just Trade'. Human Rights Watch. Retrieved 16 July 2020 from https://www.hrw. org/news/2006/11/o2/china-africa-summit-focus-human-rights-not-just-trade. HRW (2011, November 3). 'You'll Be Fired If You Refuse - Labor Abuses in Zambia's State-Owned Copper Mines'. Human Rights Watch. Retrieved 26 February 2020 from https://www.hrw.org/sites/default/files/reports/zambian11ForWebUpload.pdf.

Hurt, Stephen R. (2012). 'The EU-SADC Economic Partnership Agreement Negotiations: “Locking in” the Neoliberal Development Model in Southern Africa?' Third World Quarterly, 33(3), 495-510.

Jones, Branwen Gruffydd (ed.) (2006). Decolonizing International Relations. New York: Rowman \& Littlefield.

Kaplinsky, Raphael (2013). "What Contribution can China make to Inclusive Growth in Sub-Saharan Africa?” Development and Change, 44(6), 1295-1316.

Kayizzi-Mugerwa, Steve, Anyanwu, John C. \& Conceicao, Pedro (2014). 'Regional Integration in Africa: An Introduction'. African Development Review, 26 (s1), 1-6.

Lee, Ching Kwan (2009). 'Raw Encounters: Chinese Managers, African Workers and the Politics of Casualization in Africa's Chinese Enclaves'. China Quarterly, 199, 647-666.

Lin, Justin Yifu, and Yan Wang (2014). "China-Africa co-operation in structural transformation: Ideas, opportunities, and finances”, WIDER Working Paper, No. 2014/046. 
Marsh, Jenni (2018, March 30). 'Free Gift? China Extends Influence in Africa with \$32M Grant for Regional HQ'. CNN. Retrieved 27 September 2020 from https:// cnnphilippines.com/news/2018/o3/28/china-32M-grant-ECOWAS-regional-HQ. html.

Ministry of Foreign Affairs (2019). The Netherlands and China: A New Balance. Government of the Netherlands. https://www.government.nl/documents/ policy-notes/2019/05/15/china-strategy-the-netherlands--china-a-new-balance.

Mohan, Giles \& Lampert, Ben (2013). 'Negotiating China: Reinserting African Agency into China-Africa Relations'. African Affairs, 112(446), 92-110.

Mohan, Giles \& Tan-Mullins, May (2009). 'Chinese Migrants in Africa as New Agents of Development? An Analytical Framework'. European Journal of Development Research, 21, 588-605.

Murray-Evans, Peg (2015). 'Regionalism and African Agency: Negotiating an Economic Partnership Agreement between the European Union and SADC-Minus'. Third World Quarterly, 10, 1845-1865.

NDRC (2015, March). 'Vision and Actions on Jointly Building Silk Road Economic Belt and 21st-Century Maritime Silk Road'. National Development and Reform Commission, Ministry of Foreign Affairs and Ministry of Commerce, People's Republic of China. Retrieved 25 October 2020 from https://web.archive.org/web/20181127225143/ http://en.ndrc.gov.cn/newsrelease/201503/t20150330_669367.html.

Ndzendze, Bhaso \& Zumbika-Van Hoeymissen, Sara (2018, September 27). 'China and Africa's Integration Agenda: The Role of FOCAC'. Italian Institute for International Political Studies. Retrieved 16 July 2020 from https://www.ispionline. it/it/pubblicazione/china-and-africas-integration-agenda-role-focac-21280.

Okere, Austine (2019, August 16). 'Specialized Economic Zones (SEZs) in Africa: Exporting Production, Performance, and Perils'. Impakter. Retrieved 16 July 2020 from https://impakter.com/specialized-economic-zones-in-africa/.

Postel-Vinay, Karoline (2007). 'The Historicity of the International Region: Revisiting the Europe and the Rest' Divide'. Geopolitics 12(4), 555-569.

Quinn, Andrew (2011, June 11). 'Clinton Warns against "New Colonialism” in Africa'. Reuters. Retrieved 27 September 2020 from https:/www.reuters.com/article/ us-clinton-africa-idUSTRE75AoRI20110611.

Rebol, Max (2010). 'Public Perceptions and Reactions: Gauging African Views of China in Africa'. African Journal of Agricultural Research, 5(25), 3524-3535.

Taylor, Ian (2008). 'Sino-African Relations and the Problem of Human Rights'. African Affairs, 107(426), 63-87.

SADC (2012, August). 'Regional Infrastructure Master Plan: Executive Summary'. Southern African Development Community. Retrieved 25 October 2019 from https://www.sadc.int/files/7513/5293/3530/Regional_Infrastructure_Development_Master_Plan_Executive_Summary.pdf. 
SADC (2019, November 28). 'Chinese Government Pledges Continued Development Cooperation with SADC'. Southern African Development Community. Retrieved 16 July 2020 from https://www.sadc.int/news-events/news/ chinese-government-pledges-continued-development-cooperation-sadc/.

Samy, Yiagadeesen (2010). 'China's Aid Policies in Africa: Opportunities and Challenges'. Round Table 99(406), 75-9o.

Seth, Sanjay (2011). 'Postcolonial Theory and the Critique of International Relations'. Millennium:Journal of International Studies, 40(1), 167-183.

Shaw, Timothy (2015). 'African Agency? Africa, South Africa and the BRICS'. International Politics, 52(2), 255-268.

Söderbaum, Fredrik (2009). 'Comparative Regional Integration and Regionalism'. In Todd Landman \& Neil Robinson (eds.), The SAGE Handbook of Comparative Politics (pp. 477-496). London: SAGE.

Sun, Irene Yuan, Jayaram, Kartik \& Kassiri, Omid (2017, June). 'Dance of the Lions and Dragons: How Are Africa and China Engaging, and How Will the Partnership Evolve?' McKinsey \& Company. Retrieved 9 July 2020 from https://www.mckinsey.com/ /media/McKinsey/Featured\%2oInsights/Middle\%2oEast\%2oand\%20 Africa/The\%2oclosest\%2olook\%2oyet\%20at\%2oChinese\%2oeconomic\%2o engagement\%2oin\%2oAfrica/Dance-of-the-lions-and-dragons.pdf.

Ujeke, Charles \& Tariku, Yonas (2018). 'Beyond Symbolism: China and the African Union in African Peace and Security'. In Chris Alden, Abiodun Alao, Zhang Chun \& Lara Barber (eds.), China and Africa (pp. 289-309). Cham, Palgrave Macmillan.

US China Economic and Security Review Commission (2020, May 8). 'Hearing on “China's Strategic Aims in Africa”. Retrieved 16 July 2020 from https://www. uscc.gov/hearings/chinas-strategic-aims-africa.

US Senate Committee on Foreign Relations (2011, November 1). Subcommittee Hearing: China's Role in Africa: Implications. Subcommittee on African Affairs. Retrieved 16 July 2020 from https://www.foreign.senate.gov/hearings/ chinas-role-in-africa-implications.

Uzodike, Nwabufo Okeke (2009). 'The Role of Regional Economic Communities in Africa's Economic Integration: Prospects and Constraints'. Africa Insight, 39(2), 26-42.

Van Mead, Nick (2018, July 31). 'China in Africa: Win-Win Development, or a New Colonialism?' The Guardian. Retrieved 27 September 2020 from https://www. theguardian.com/cities/2018/jul/31/china-in-africa-win-win-development-ora-new-colonialism.

Van Staden, Cobus, Alden, Chris \& Wu, Yu-shan. (2018, September). 'In the Driver's Seat? African Agency and Chinese Power at FOCAC, the AU and the BRI'. Occasional Paper 286. South African Institute of International Affairs (SAIIA). 
Wang, Jianwei \& Zou, Jing (2014). 'China Goes to Africa: A Strategic Move?' Journal of Contemporary China, 23 (90), 1113-1132.

Zhang, Zhexin (2018). 'The Belt and Road Initiative: China's New Geopolitical Strategy?' China Quarterly of International Strategic Studies, 4(3), 327-343.

\section{About the Author}

Dr. StAcey Links is a South African national based in the Netherlands as a Research Fellow at the LeidenAsiaCentre. Having obtained her PhD from Utrecht University's Department of Law, Governance and Economics, she now holds the position of Lecturer at Leiden University's Institute of Area Studies (LIAS), where her teaching focuses on China-Africa relations, postcolonial and critical international relations theory, as well as regional integration in Sub-Saharan Africa. Her research interests are human rights in China-Africa relations and specifically the right to development. Her research is set against the backdrop of critical IR theory as well as critical approaches to development. 
